\title{
A simple route to dinuclear complexes of a sulfonamide ligand with a potential interest in the catalysis field
}

\author{
Jesús Sanmartín-Matalobos, * Cristina Portela-García, Matilde Fondo and \\ Ana M. García-Deibe \\ Dpto. de Química Inorgánica, Fac. de Química, Univ. de Santiago de \\ Compostela, Campus Vida, E-15782 Santiago de Compostela, Spain. \\ E-mail: jesus.sanmartin@usc.es
}

\begin{abstract}
We report here the straightforward synthesis of some $d$-block metal dimers of a Schiff base ligand obtained by condensation of 2-tosylaminomethylaniline with 4formyl-3-hydroxybenzoic acid $\left(\mathrm{H}_{2} \mathrm{~L}\right)$. The easy bideprotonation of both $-\mathrm{OH}$ and $-\mathrm{HNSO}_{2}$ - groups, as well as a suitable $N, N, O$ binding domain that can simultaneously bind two metal ions through $\mu_{2}-N_{\text {sulfonamido }}$ bridges have been considered during the design step of the Schiff base ligand. All the compounds synthesised were characterised by a combination of mass spectrometry, infrared spectroscopy, elemental analysis and, when applicable, by ${ }^{1} \mathrm{H}$ NMR spectroscopy. We have used NOESY experiments for structure elucidation of $\mathrm{H}_{2} \mathrm{~L}$ and $\left(\mathrm{NH}_{4}\right)_{2}\left[\mathrm{Pd}_{2} \mathrm{~L}_{2}\right] \cdot 2 \mathrm{H}_{2} \mathrm{O}$ in solution.
\end{abstract}

\section{Keywords}

Dinuclear complexes / $d$-block metals / Schiff bases / enolimines

\section{Introduction}

Our research efforts to synthesise dinuclear metal complexes of sulfonamide ligands with a potential interest in the catalysis field arises from the reported use of $\mathrm{Zn}_{2} \mathrm{~L}_{2} \mathrm{Et}_{2}$ (Fig. 1) as an efficient catalyst in the synthesis of poly(L-lactide)-Vitamin $\mathrm{E}$ TPGS nanoparticles (TPGS = tocopheryl polyethylene glicol succinate) [1]. One might note that the tridentate Schiff base ligand used to obtain $\mathrm{Zn}_{2} \mathrm{~L}_{2} \mathrm{Et}_{2}$ derives from the mono-condensation of a salicylaldehyde derivative and 2-tosylaminobenzylamine, which has been first synthetised by us [2]. 


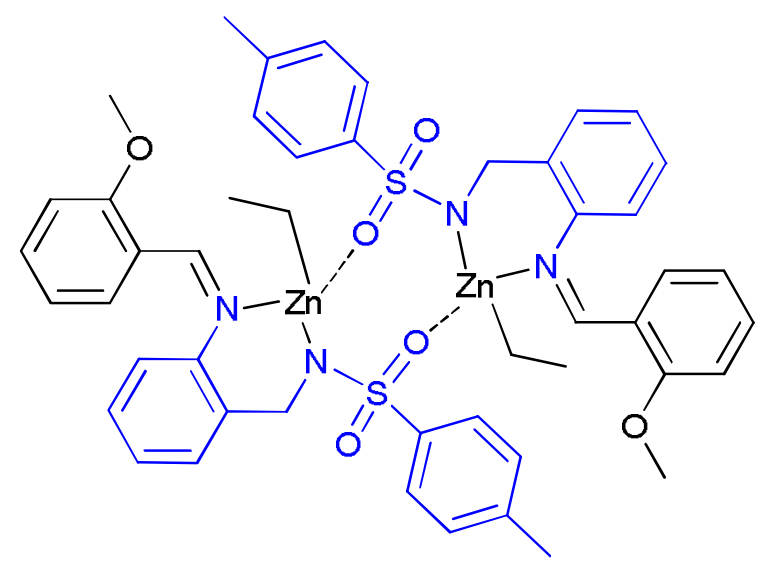

Fig. 1. Proposed structure [1] for $\mathrm{Zn}_{2} \mathrm{~L}_{2} \mathrm{Et}_{2}$ with the 2-tosylaminobenzylamine residue highlighted in blue colour.

With the aim of synthesising dinuclear metal complexes of sulfonamide ligands, we have designed a monotopic Schiff base ligand (scheme 1), which derives from the reaction of 2-tosylaminobenzylamine [2] with 4-formyl-3-hydroxybenzoic acid $\left(\mathrm{H}_{2} \mathrm{~L}\right)$. The easy bideprotonation of both - $\mathrm{OH}$ and $-\mathrm{HNSO}_{2}$ - groups, as well as a suitable $\mathrm{N}, \mathrm{N}, \mathrm{O}$ binding domain that can simultaneously bind two metal ions through $\mu_{2}-N_{\text {sulfonamido }}$ bridges have been considered during the design step.

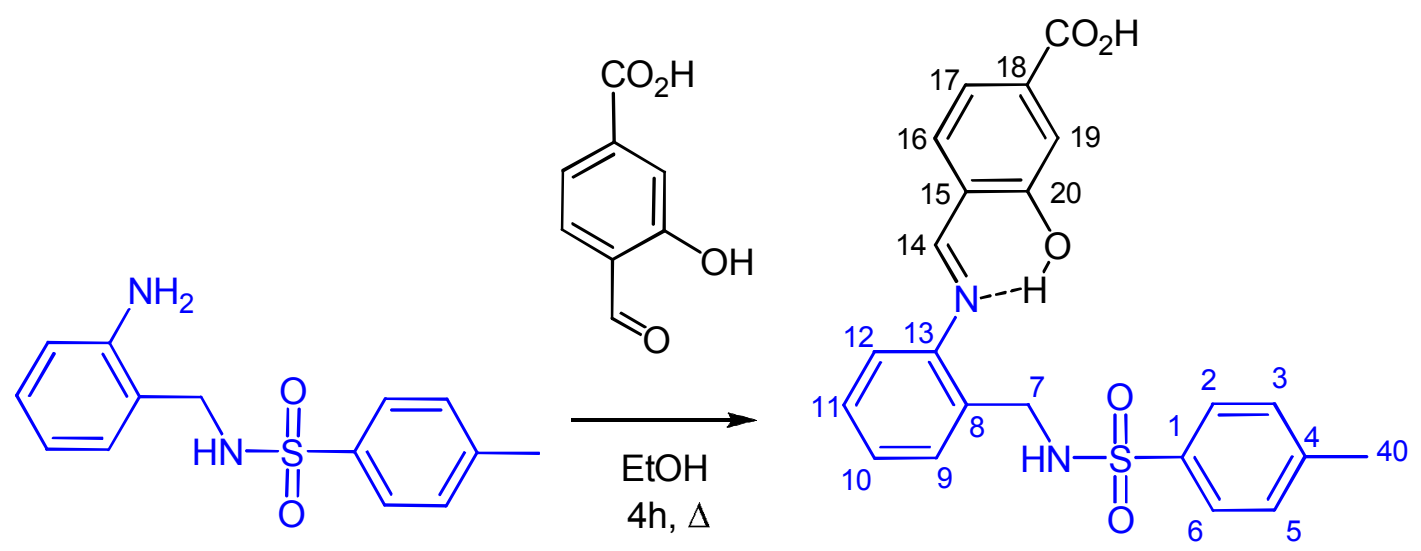

Scheme 1. Schematic representation of the synthesis of $\mathrm{H}_{2} \mathrm{~L}$, showing the numbering scheme for NMR studies.

\section{Material and methods}

Synthesis of $\mathrm{H}_{2} \mathrm{~L}$

$\mathrm{H}_{2} \mathrm{~L}$ could be obtained after cooling at room temperature an absolute ethanol solution $(40 \mathrm{~mL})$ containing 4-formyl-3-hydroxybenzoic acid $(0.09 \mathrm{~g}, 0.55 \mathrm{mmol})$ and 2- 
tosylaminomethylaniline [2] $(0.15 \mathrm{~g}, 0.55 \mathrm{mmol})$ that had been refluxing for 4 hours. The pale yellow precipitate formed was separated and air-dried.

Yield $=0.21 \mathrm{~g}(92 \%) . \mathrm{Mp}=134{ }^{\circ} \mathrm{C} .{ }^{1} \mathrm{H}$ NMR $\left(500 \mathrm{MHz}\right.$, DMSO- $d_{6}, \delta$ in ppm): 13.03 (s, 1H, HOCO), 12.33 (s, 1H, HO20), 8.79 (s, 1H, H14), 8.00 (t, 1H, HN), 7.78 (d, 1H, H16), 7.63 (d, 1H, H2 + H6), 7.51 (d, 1H, H17), 7.46 (s, 1H, H19), 7.38 (d, 1H, H9), 7.36 (t, 1H, H11), 7.29 (d, 2H, H3 + H5), 7.28 (t, 1H, H10), 7.21 (d, 1H, H12), 4.08 (d, 2H, H7), 2.34 (s, 3H, H40). ${ }^{13} \mathrm{C}$ NMR (125 MHz, DMSO- $d_{6}, \delta$ en ppm): 167.1(COOH), 162.6 (C14), 147.6 (C13), 132.2 (C16), 129.8 (C3 + C5), 129.1 (C9), 129.0 (C11), 127.0 (C2 + C6), 120.0 (C17), 119.5 (C10), 119.0 (C12), 117.6 (C19), 42.6 (C7), 21.5 (C40). IR (KBr, v/cm $\left.{ }^{-1}\right): v(\mathrm{OH}) 3442, v(\mathrm{OH}) 3315, v\left(\mathrm{C}=\mathrm{N}_{\text {imine }}\right) 1695$, $v_{a s}\left(\mathrm{SO}_{2}\right)$ 1329, $v_{s}\left(\mathrm{SO}_{2}\right)$ 1151. $\mathrm{MS}\left(\mathrm{ESI}^{+}, \mathrm{MeOH} / \mathrm{HCOOH}\right) m / z: 425.2\left[\mathrm{H}_{2} \mathrm{~L}+\mathrm{H}\right]^{+}$. Elemental Analysis: C 61.9; $\mathrm{H} 4.8 ; \mathrm{N} 6.6 ; \mathrm{S} 7.5 \%$; calc. for $\mathrm{C}_{22} \mathrm{H}_{20} \mathrm{~N}_{2} \mathrm{O}_{5} \mathrm{~S}: \mathrm{C} 62.3 ; \mathrm{H}$ 4.8; N 6.6; S 7.6\%.

Syntheses of the complexes

$\left(\mathrm{NH}_{4}\right)_{2}\left[\mathrm{Pd}_{2} \mathrm{~L}_{2}\right] \cdot 2 \mathrm{H}_{2} \mathrm{O}$

A methanol solution $(20 \mathrm{~mL})$ of $\mathrm{H}_{2} \mathrm{~L}(0.10 \mathrm{~g}, 0.24 \mathrm{mmol})$ was added to other methanol solution $(20 \mathrm{~mL})$ of $\mathrm{Pd}(\mathrm{OAc})_{2}(0.05 \mathrm{~g}, 0.24 \mathrm{mmol})$, and then 2 drops of an aqueous solution of $\mathrm{NH}_{3}(17 \%)$ This mixture was refluxed for $4 \mathrm{~h} 30 \mathrm{~min}$ to yield a suspension that was filtered off, washed with warm methanol $(10 \mathrm{~mL})$ and then airdried.

Yield: $0.14 \mathrm{~g}$ (52\%). ${ }^{1} \mathrm{H}$ RMN (500 MHz, DMSO- $\left.d_{6}, \delta / \mathrm{ppm}\right): 8.12$ (s, 2H, H14), 7.61 (d, 2H, H16), 7.58 (d, 4H, H2 + H6), 7.34 (s, 2H, H19), 7.12 (d+t, 4H, H9+H11), $7.07(\mathrm{t}+\mathrm{d}, 4 \mathrm{H}, \mathrm{H} 10+\mathrm{H} 17), 6.88(\mathrm{~d}, 4 \mathrm{H}, \mathrm{H} 3+\mathrm{H} 5), 6.84$ (d, 2H, H12), 4.14 (d, 4H, H7), $3.66\left(\mathrm{~s}, 8 \mathrm{H}, \mathrm{NH}_{4}^{+}\right), 2.18$ (s, 6H, H40). $\left.{ }^{13} \mathrm{C} \mathrm{RMN} \mathrm{(125} \mathrm{MHz,} \mathrm{DMSO-} d_{6}, \delta / \mathrm{ppm}\right): 167.6$ (COO), 164.2 (C20), 162.7 (C14), 144.9 (C13), 142.5 (C1), 139.8 (C4), 137.6 (C18), 137.1 (C16), 133.4 (C8), 129.5 (C10), 128.8 (C9), 128.3 (C3 + C5), 126.8 (C11), 126.1 (C2+C6), 123.7 (C15), 121.7 (C12), 121.5 (C19), 114.9 (C17), 50.2 (C7), 21.2 (C40). IR $\left(\mathrm{KBr}, v / \mathrm{cm}^{-1}\right): v\left(\mathrm{OH}_{\mathrm{w}}\right) 3436, v\left(\mathrm{NH}_{4}{ }^{+}\right) 3372,3340, v(\mathrm{COO}) 1724, v(\mathrm{C}=\mathrm{N}) 1607$, $v_{a s}\left(\mathrm{SO}_{2}\right) 1384, v_{s}\left(\mathrm{SO}_{2}\right)$ 1134. Elemental analysis: $\mathrm{C} 47.1 ; \mathrm{H} 4.2 ; \mathrm{N} 7.5 ; \mathrm{S} 5.7 \%$; calc. for $\mathrm{C}_{44} \mathrm{H}_{46} \mathrm{~N}_{6} \mathrm{O}_{12} \mathrm{Pd}_{2} \mathrm{~S}_{2}: \mathrm{C} 46.9 ; \mathrm{H} 4.1 ; \mathrm{N} 7.5 ; \mathrm{S} 5.7 \%$. 
$\mathrm{Zn}_{2} \mathrm{~L}_{2} \cdot 4 \mathrm{H}_{2} \mathrm{O}$

The zinc complex has been obtained by electrochemical oxidation of a metal anode immersed in an acetonitrile solution $(80 \mathrm{~mL})$ of $\mathrm{H}_{2} \mathrm{~L}(0.05 \mathrm{~g}, 0.12 \mathrm{mmol})$, containing tetraethylammonium perchlorate (ca. $50 \mathrm{mg}$ ) as supporting electrolyte (Caution: Although no problem has been encountered in this work, all perchlorate compounds are potentially explosive and should be handled in small quantities and with great care!). This was electrolysed for about $1 \mathrm{~h}$ and $25 \mathrm{~min}$ at a current intensity of $5.0 \mathrm{~mA}$ and an initial voltage of $5 \mathrm{~V}$. The resulting yellow precipitate was filtered off, washed with acetonitrile $(10 \mathrm{~mL})$ and then air-dried.

Yield: 0.10 g (80\%). MS (MALDI-TOF ${ }^{+}$, DCTB) $m / z: 977.1\left[\mathrm{Zn}_{2} \mathrm{~L}_{2}+\mathrm{H}\right]^{+}$. IR $(\mathrm{KBr}$, $\left.v / \mathrm{cm}^{-1}\right): v\left(\mathrm{O}-\mathrm{H}_{\mathrm{w}}\right)$ 3436, $v(\mathrm{O}-\mathrm{H})$ 3280, $v(\mathrm{C}=\mathrm{O}) \quad 1697, v(\mathrm{C}=\mathrm{N})$ 1614, $v_{a s}\left(\mathrm{SO}_{2}\right)$ 1326, $v_{s}\left(\mathrm{SO}_{2}\right)$ 1158. Elemental analysis: $\mathrm{C} 50.1 ; \mathrm{H} 4.6 ; \mathrm{N} 5.1 ; \mathrm{S} 5.9 \%$, calc. for $\mathrm{C}_{44} \mathrm{H}_{44} \mathrm{~N}_{4} \mathrm{O}_{14} \mathrm{~S}_{2} \mathrm{Zn}_{2}$ : C 50.4; $\mathrm{H} 4.2 ; \mathrm{N} 5.4 ; \mathrm{S} 6.1 \%$.

$\mathrm{Co}_{2} \mathrm{~L}_{2} \cdot 4 \mathrm{H}_{2} \mathrm{O}$

The cobalt complex has been obtained by electrochemical oxidation of a metal anode immersed in an acetonitrile solution $(60 \mathrm{~mL})$ of $\mathrm{H}_{2} \mathrm{~L}(0.05 \mathrm{~g}, 0.12 \mathrm{mmol})$, containing tetraethylammonium perchlorate (ca. $50 \mathrm{mg}$ ) as supporting electrolyte (Caution: Although no problem has been encountered in this work, all perchlorate compounds are potentially explosive and should be handled in small quantities and with great care!). This was electrolysed for about $1 \mathrm{~h}$ and $25 \mathrm{~min}$ at a current intensity of $5.1 \mathrm{~mA}$ and an initial voltage of $5 \mathrm{~V}$. The resulting brown precipitate was filtered off, washed with acetonitrile $(20 \mathrm{~mL})$ and then air-dried.

Yield: 0.04g (61\%). MS (MALDI-TOF ${ }^{+}$, DCTB) m/z: $963.1\left[\mathrm{Co}_{2} \mathrm{~L}_{2}+\mathrm{H}\right]^{+}$. IR $(\mathrm{KBr}$, $\left.v / \mathrm{cm}^{-1}\right): v\left(\mathrm{O}-\mathrm{H}_{\mathrm{w}}\right) 3435, v(\mathrm{C}=\mathrm{N}) 1613, v_{a s}\left(\mathrm{SO}_{2}\right) 1324, v_{s}\left(\mathrm{SO}_{2}\right)$ 1159. Elemental analysis: C 50.9; H 4.1; N 5.3; S 6.0\%, calc. for $\mathrm{C}_{44} \mathrm{H}_{44} \mathrm{Co}_{2} \mathrm{~N}_{4} \mathrm{O}_{14} \mathrm{~S}_{2}$ : C 51.1; H 4.3; N 5.4; $\mathrm{S}$ $6.2 \%$.

$\mathrm{Ni}_{2} \mathrm{~L}_{2} \cdot 4 \mathrm{H}_{2} \mathrm{O}$

The nickel complex has been obtained by electrochemical oxidation of a metal anode immersed in an acetonitrile solution $(60 \mathrm{~mL})$ of $\mathrm{H}_{2} \mathrm{~L}(0.05 \mathrm{~g}, 0.12 \mathrm{mmol})$, containing tetraethylammonium perchlorate (ca. $50 \mathrm{mg}$ ) as supporting electrolyte (Caution: Although no problem has been encountered in this work, all perchlorate compounds are potentially explosive and should be handled in small quantities and with great care!). 
This was electrolysed for about $1 \mathrm{~h}$ and $25 \mathrm{~min}$ at a current intensity of $5.1 \mathrm{~mA}$ and an initial voltage of $5 \mathrm{~V}$. The resulting brown precipitate was filtered off, washed with acetonitrile $(20 \mathrm{~mL})$ and then air-dried.

Yield: 0.04g (60\%). MS (MALDI-TOF ${ }^{+}$DCTB) $m / z: 963.2\left[\mathrm{Ni}_{2} \mathrm{~L}_{2}+\mathrm{H}\right]^{+}$. IR $(\mathrm{KBr}, v$ $\left./ \mathrm{cm}^{-1}\right): v\left(\mathrm{O}-\mathrm{H}_{\mathrm{w}}\right) 3430, v(\mathrm{C}=\mathrm{N}) 1618, v_{a s}\left(\mathrm{SO}_{2}\right) 1323, v_{s}\left(\mathrm{SO}_{2}\right)$ 1159. Elemental analysis: C 51.4; H 4.5; N 5.6; S 6.1\%, calc. for $\mathrm{C}_{44} \mathrm{H}_{44} \mathrm{~N}_{4} \mathrm{Ni}_{2} \mathrm{O}_{14} \mathrm{~S}_{2}$ : C 51.1; H 4.3; N 5.4; $\mathrm{S} 6.2 \%$.

\section{Physical measurements}

The free ligand and its complexes were characterised by a combination of elemental

analysis, infrared spectroscopy, mass spectrometry and, when applicable, by ${ }^{1} \mathrm{H}$ NMR spectroscopy.

Elemental analyses of $\mathrm{C}, \mathrm{H}$ and $\mathrm{N}$ were performed on a Carlo Erba EA 1108 analyzer. IR spectra were recorded as $\mathrm{KBr}$ pellets on a FT-IR Mattson Instruments 202Q spectrophotometer in the range $4000-600 \mathrm{~cm}^{-1}$. MALDI-TOF mass spectra were recorded on a Bruker Ultraflex III TOF/TOF using methanol as solvent and DCTB as matrix. ${ }^{1} \mathrm{H}$ NMR spectra were recorded on a Bruker DPX-250 spectrometer using DMSO- $d_{6}$ as solvent.

\section{Results and discussion}

$\mathrm{H}_{2} \mathrm{~L}$

The Schiff base ligand, along with negligible amounts of the ring tautomer (tetrahydroquinazoline), has been synthesised via nucleophilic addition of 2-tosylaminomethylaniline [2] to 4-formyl-3-hydroxybenzoic acid.

The 2-D NOESY spectrum of $\mathrm{H}_{2} \mathrm{~L}$ (Fig. 2) shows cross peaks due to the coupling of the imine proton (H-14, at about $8.8 \mathrm{ppm}$ ) with aromatic protons $\mathrm{H}-12$ (at about 7.2 ppm) and H-16 (at about $7.8 \mathrm{ppm}$ ). The results of the NOESY experiment allow elucidating the conformation adopted by $\mathrm{H}_{2} \mathrm{~L}$ in solution, which is shown in Scheme 1. The $E$ configuration displayed by the enolimine tautomer is favoured by an intramolecular H-bond between the 2-hydroxyl substituent and the $-\mathrm{HC}=\mathrm{N}$ - group. The strength of this bond appears to be the cause for the stabilisation of the enolimine form $[3]$. 


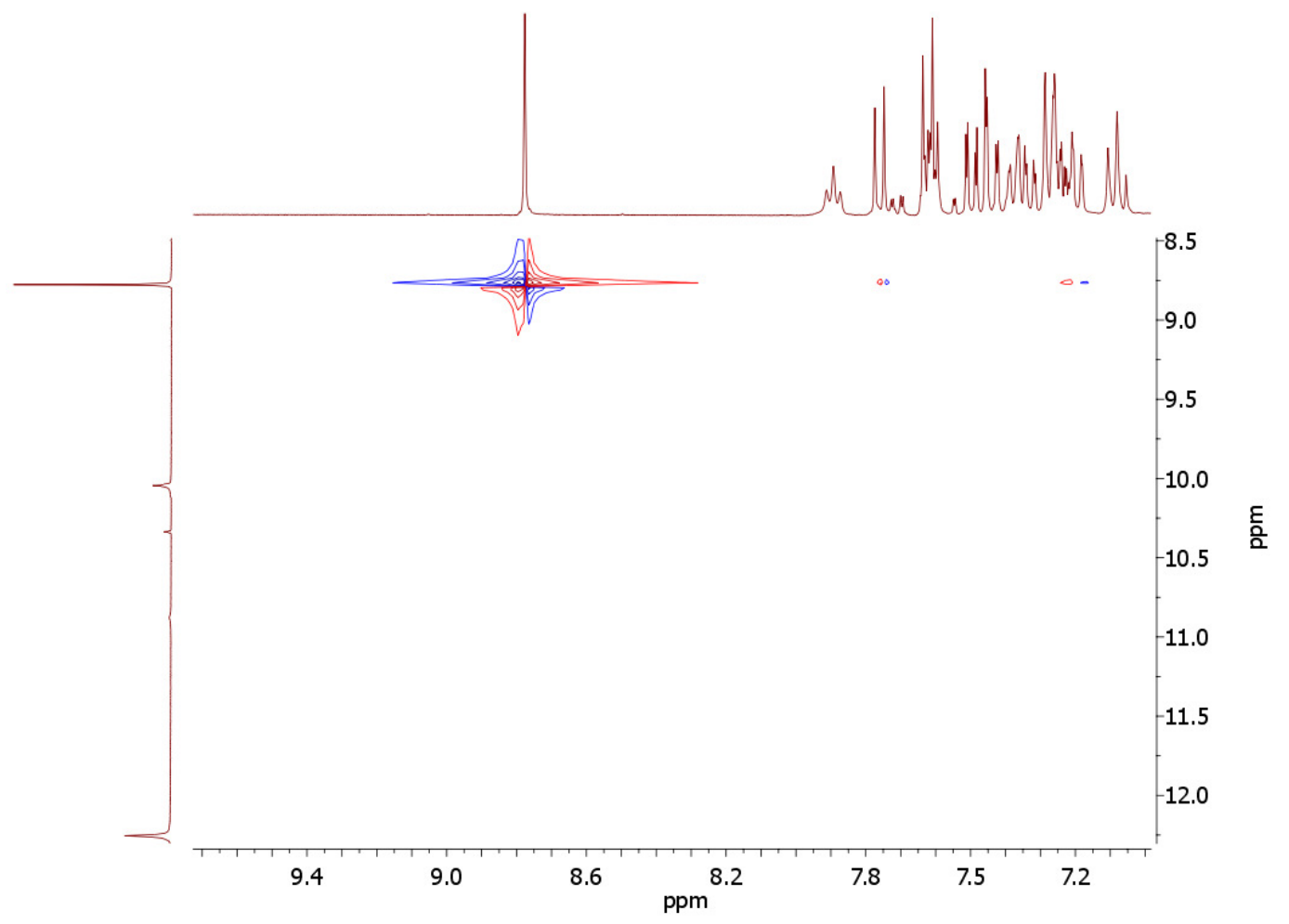

Fig. 2. Partial view of the NOESY spectrum of $\mathrm{H}_{2} \mathrm{~L}$ showing the coupling of the imine proton (H-14, at about $8.8 \mathrm{ppm}$ ) with aromatic protons $\mathrm{H}-12$ (at about $7.2 \mathrm{ppm}$ ) and $\mathrm{H}-16$ (at about $7.8 \mathrm{ppm})$.

Metal complexes.

$\left(\mathrm{NH}_{4}\right)_{2}\left[\mathrm{Pd}_{2} \mathrm{~L}_{2}\right] \cdot 2 \mathrm{H}_{2} \mathrm{O}$ has been synthesised in low yield by reaction of $\mathrm{Pd}(\mathrm{OAc})_{2}$ with $\mathrm{H}_{2} \mathrm{~L}$ in the presence of two drops of an aqueous solution of $\mathrm{NH}_{3}$. With the aim of synthesising dinuclear metal complexes of sulfonamide ligands with higher yields, we have investigated the use of an electrochemical method for the synthesis of some $d$ block metal complexes. As a result $\mathrm{Zn}_{2} \mathrm{~L}_{2} \cdot 4 \mathrm{H}_{2} \mathrm{O}, \mathrm{Co}_{2} \mathrm{~L}_{2} \cdot 4 \mathrm{H}_{2} \mathrm{O}$ and $\mathrm{Ni}_{2} \mathrm{~L}_{2} \cdot 4 \mathrm{H}_{2} \mathrm{O}$ have been synthesised. These complexes could be characterised by a combination of mass spectrometry, infrared spectroscopy, elemental analysis, and, when applicable, by ${ }^{1} \mathrm{H}$ NMR spectroscopy.

MALDI-TOF mass spectra of the complexes have evidenced their dinuclear nature, being possible the identification of intense signals assignable to molecular ions of the type $\left[\mathrm{M}_{2} \mathrm{~L}_{2}+\mathrm{H}\right]^{+}$. Fig. 3 shows a partial view of the MALDI-TOF mass spectra of $\mathrm{Ni}_{2} \mathrm{~L}_{2} \cdot 4 \mathrm{H}_{2} \mathrm{O}$ and $\mathrm{Co}_{2} \mathrm{~L}_{2} \cdot 4 \mathrm{H}_{2} \mathrm{O}$. Basing on the reported crystal structure of $\mathrm{Cu}_{2} \mathrm{~L}_{2} \cdot 2 \mathrm{MeCN}$ [4], we propose here that the repeating units are held together by $\mu-\mathrm{N}_{\text {sulfonamido }}$ bridges 
between the metal centres rather than by $\mathrm{M}-\mathrm{O}_{\text {tosyl }}$ bonds. The type of link here proposed has been already found in dinuclear metal complexes of sulfonamide ligands involved in catalysis [5].
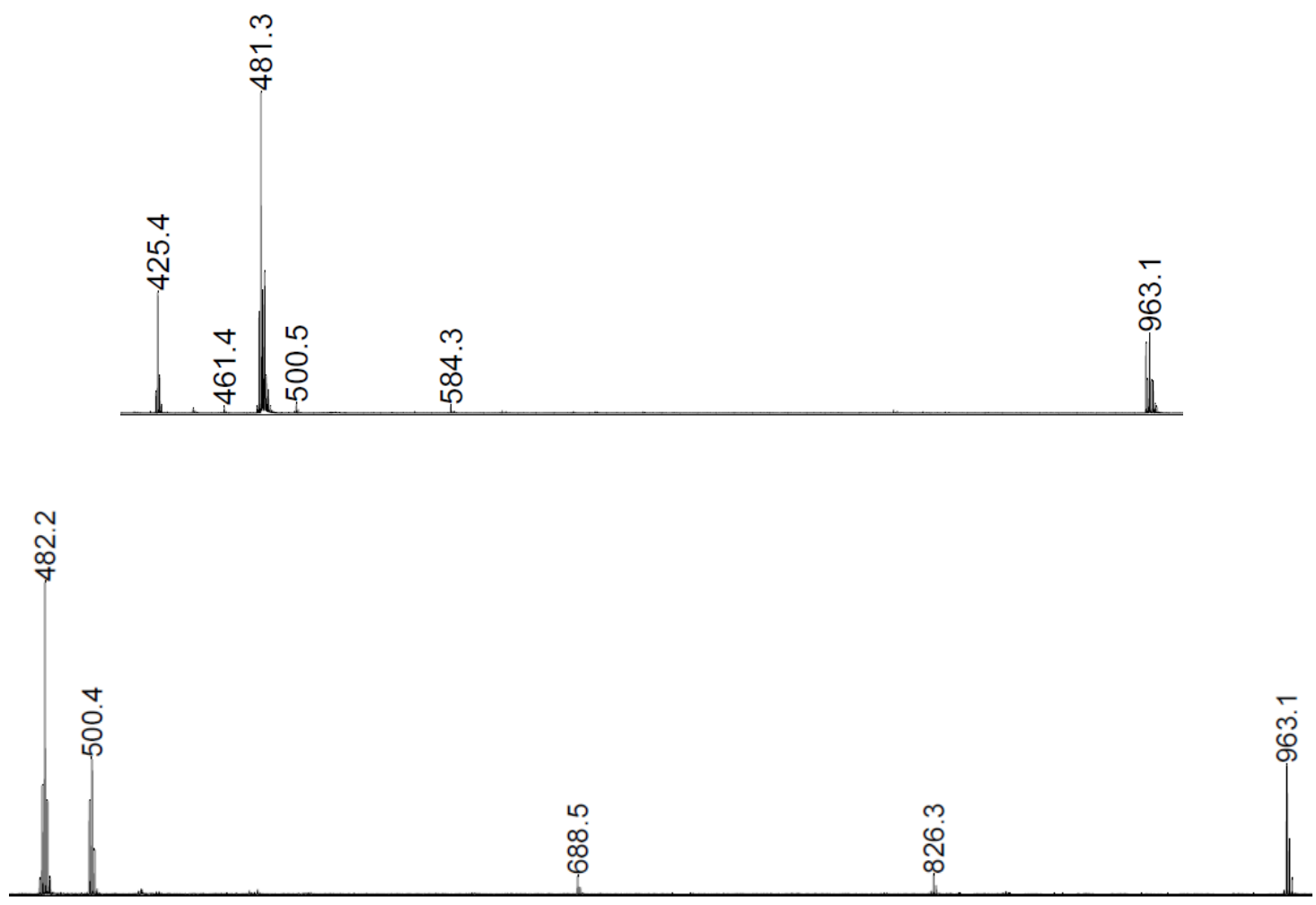

Fig. 3. Partial view of the MALDI-TOF mass spectra of $\mathrm{Ni}_{2} \mathrm{~L}_{2} \cdot 4 \mathrm{H}_{2} \mathrm{O}$ (top) and $\mathrm{Co}_{2} \mathrm{~L}_{2} \cdot 4 \mathrm{H}_{2} \mathrm{O} \cdot($ bottom) in DCTB.

Fig. 4 shows the ${ }^{1} \mathrm{H}$ NMR spectrum of $\left(\mathrm{NH}_{4}\right)_{2}\left[\mathrm{Pd}_{2} \mathrm{~L}_{2}\right] \cdot 2 \mathrm{H}_{2} \mathrm{O}$. Since the spectrum of $\left(\mathrm{NH}_{4}\right)_{2}\left[\mathrm{Pd}_{2} \mathrm{~L}_{2}\right] \cdot 2 \mathrm{H}_{2} \mathrm{O}$ evidencing homotopic methylene protons in dmso- $d_{6}$ ( $\delta$ about 4.1 ppm), we have assumed that the two methylene protons can interconvert easily by fast change in the envelope conformation of six-membered metallacycles of aniline residues, becoming $\mathrm{H} 7$ protons equivalent.

The 2-D NOESY spectrum of $\left(\mathrm{NH}_{4}\right)_{2}\left[\mathrm{Pd}_{2} \mathrm{~L}_{2}\right] \cdot 2 \mathrm{H}_{2} \mathrm{O}$ shows cross peaks due to the coupling of the imine proton (H-14) with aromatic protons H-12 and H-16 (Fig. 5, blue line). In view of the rigidity of $\left(\mathrm{NH}_{4}\right)_{2}\left[\mathrm{Pd}_{2} \mathrm{~L}_{2}\right] \cdot 2 \mathrm{H}_{2} \mathrm{O}$, these couplings allow elucidating its conformation in solution, which is shown in Fig. 4 (inset). 


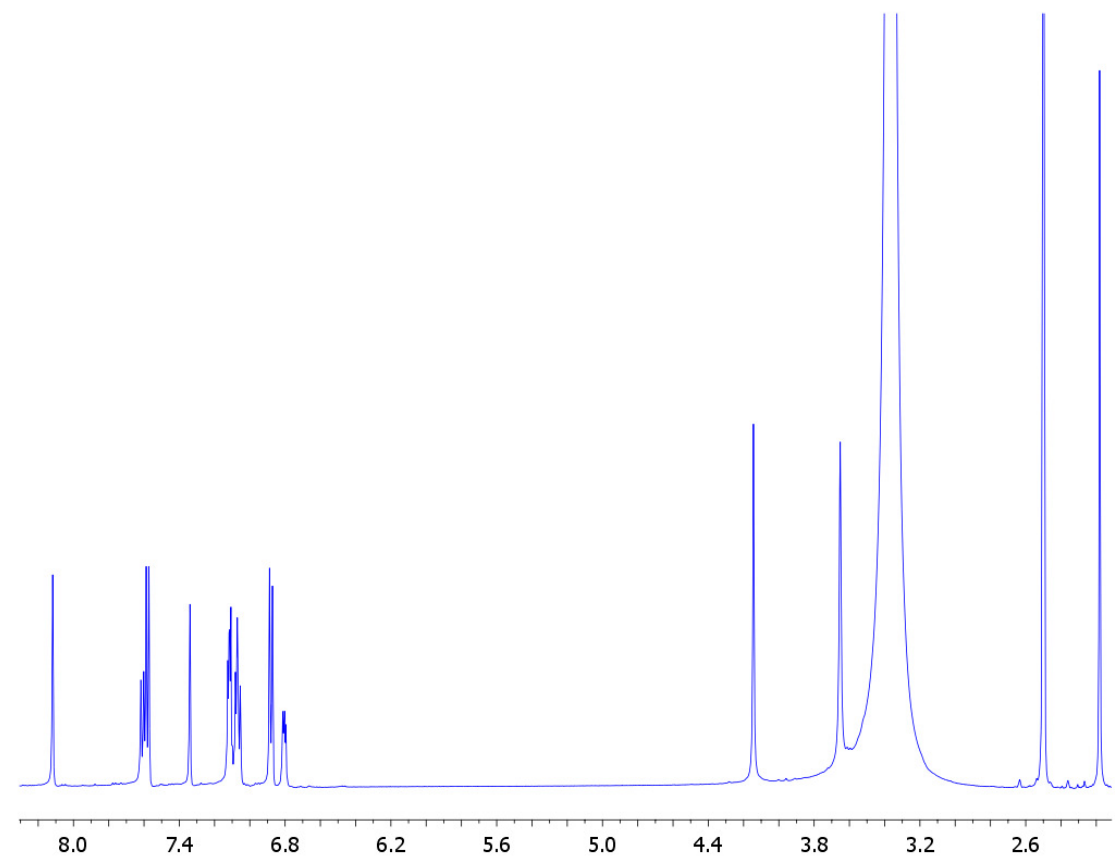

Fig.4. ${ }^{1} \mathrm{H}$ NMR spectrum of $\left(\mathrm{NH}_{4}\right)_{2}\left[\mathrm{Pd}_{2} \mathrm{~L}_{2}\right] \cdot 2 \mathrm{H}_{2} \mathrm{O}$ in dmso- $d_{6}$.

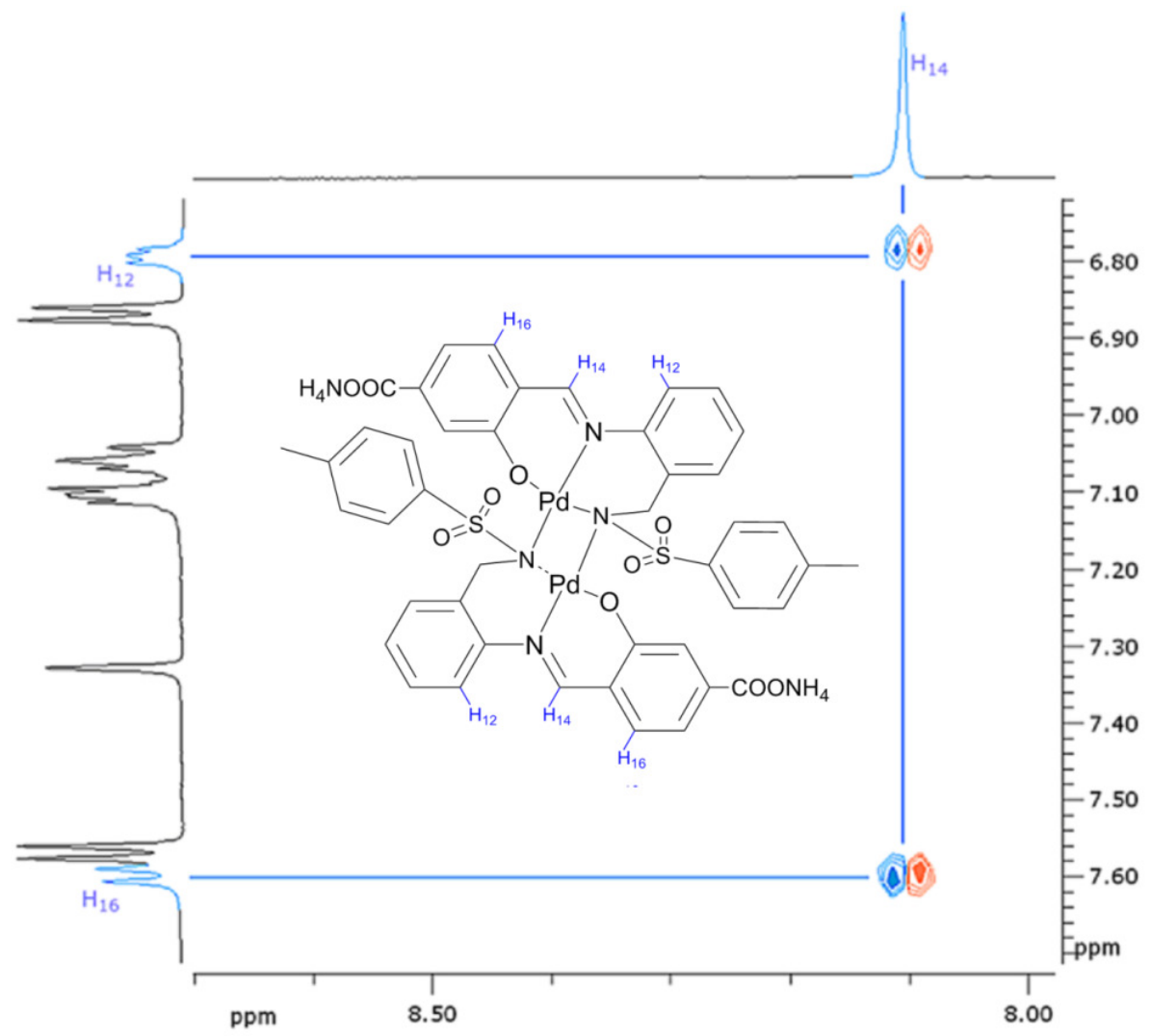

Fig.5. Partial view of the NOESY spectrum of $\left(\mathrm{NH}_{4}\right)_{2}\left[\mathrm{Pd}_{2} \mathrm{~L}_{2}\right] \cdot 2 \mathrm{H}_{2} \mathrm{O}$ in DMSO- $d_{6}$ 


\section{Conclusions}

We have demonstrated that the $N$-tosylated tridentate Schiff base ligand derived from the condensation of 2-tosylaminomethylaniline with 4-formyl-3-hydroxybenzoic acid $\left(\mathrm{H}_{2} \mathrm{~L}\right)$ is adequate to obtain dimeric complexes with some $d$-block metal ions. Further studies will be necessary to assay the catalytic activity the synthesised dinuclear complexes.

\section{References}

[1] P.-Y. Li, P.-S. Lai, W.-C. Hung, W.-J. Syu, Biomacromolecules 11 (2010) 2576.

[2] J. Sanmartín, F. Novio, A.M. García-Deibe, M. Fondo; M.R. Bermejo, New. J. Chem., 31 (2007) 1605.

[3] A.M. García-Deibe, C. Portela-García, M. Fondo, J. Sanmartín-Matalobos, RSC Adv. (2015) 58327.

[4] J. Sanmartín, F. Novio, A.M. García-Deibe, M. Fondo, N. Ocampo, M.R. Bermejo, Eur. J. Inorg. Chem. 10 (2008) 1719.

[5] K. Ishiwata, S. Kuwata, T. Ikariya, J. Am. Chem. Soc. 131 (2009) 5001. 